\title{
Landscape of Dolní Kounice from the perspective of the authors of the Franciscan ("Stabile") Cadastre
}

\author{
PETR DVOŘÁK \\ Institute of Geonics, Academy of Sciences of the Czech Republic, \\ Department of Environmental geography in Brno
}

\begin{abstract}
The aim of this contribution is to refer to the exceptional function of the Franciscan, so-called "Stabile" Cadastre in landscape description of the first half of the $19^{\text {th }}$ century. The Franciscan Cadastre is an outstanding piece of work, both for its high historic and aesthetic value as well as for its detailed depiction of not only land use but also elementary description of social and economic aspects of the settlements during the beginnings of the Industrial and the Agricultural Revolution in the Czech lands. The Franciscan Cadastre is a perfect tool for research on landscape structures, as it consists of the map records in which the actual landscape situation was recorded with the assistance of precise cartographic techniques, and thus allows us to study its spatial structure; the written records provide us with quantitative information about land use and way of farming.

The essence of this contribution is the data analysis making use of the Franciscan Cadastre of Dolní Kounice, and creating a compact "picture" of the area on the basis of social, material-technical and economic situation, which is described in the written records of the Franciscan Cadastre of the town. The pillar of such picture is the data concerning population and its way of living, farming methods, crops cultivated and animals bred. Specific attention is paid to ten categories of land use in Dolní Kounice, which are delimited in the written records of the Franciscan Cadastre. They are: arable land, pastures, vineyards, gardens, builtup areas, forest, arable land with fruit trees, pastures with fruit trees, pastures with trees and shrubs, and crop-fallow rotation, with which we can further on specify the way of farming, proprietary relations and the size of land blocks, using the map cadastral records.

The landscape structure described in the Franciscan Cadastre (1841) is compared with the data from 1845 that is used when studying long-term changes of land use based on the statistical data (LUCC UK Prague database).
\end{abstract}

Key words: landscape, Franciscan Cadastre, Stabile Cadastre, land use changes

\section{Introduction}

Not only geographers (Bičík 2004, Jeleček 1995, Brůna, Křováková 2006, Boltižiar et al. 2008, Olah 2003, and the like) but also historians (Kašpar 1997, Semotanová 2001), landscape ecologists and environmentalists and sociologists (Lipský 2000, Sádlo, Karlík 2002, Cílek 2004) have been dealing with landscape development, its historical or dynamic land use, over the past two decades. The reason of such expansion 
of this research specialization in geography is a big boom in computer technology and equipment, and relatively easily accessible data, which now allows us to make a range of comparable "landscape pictures" starting from the first half of the $19^{\text {th }}$ century. When creating the time series that are utilized for the landscape development assessment, two pillars of historical land use study are applied. One of them is the analysis of the cartographic base, aerial and satellite photographs.

This base records the actual state of the area at the time of the origin of the given work, that is, the actual land use including size characteristic of individual sites, their spatial differentiation and mutual relations. The second pillar is the statistical data based on cadastral investigation and presenting hard data about basic land use - about the type and the size of individual land use types. Nowadays most of works combine both two data sources; in the studies focused on individual cadastres or on smaller areas data acquired from maps prevail (Olah 2003, Lipský 2000, Brůna, Křováková 2006), within the scale of districts and Regions, or the whole Czech Republic - pure statistical data prevails (Bičík 2004, Kabrda 2004, Bičík, Jeleček 2003, Jeleček 1995), or map base (Mackovčin, Demek, Havlíček 2007) or satellite photographs - the project works of CORINE LAND COVER (Feranec 2009).

The development assessment of land use of the Czech Lands on the basis of cartographic data usually begins with map processing of the First Military Survey (1764-1768), for methodical reasons (inaccurate cartographic map processing does not allow us to georeference maps in GIS environment) only the maps of the Second Military Survey get fully used. This Survey was carried out in two stages in the Czech Lands: in Moravia and Silesia between 1836-1840, in Bohemia between 1842 and 1852. The base of this Survey was the Franciscan Cadastre whose maps originated in Bohemia between 1826-1843, in Moravia and Silesia between 1826 and 1836. The Franciscan Cadastre is thus the oldest and thanks to its scale of 1:2880, the most detailed map source for landscape study, fully comparable with more recent maps (see e.g., Kuchař 1961, 1967, Bumba 2007 Semotanová 2001 for more details).

The time period of the first half of the $19^{\text {th }}$ century, within which the Franciscan Cadastre originated, is crucial indeed both for the Czech society and its landscape. Within this short time period a lot of changes happened that penetrated the whole society and got also reflected in the landscape. Fundamental changes resulted from the Industrial and the Agricultural Revolution. Both of them were in progress almost simultaneously since the turn of the $18^{\text {th }}$ and $19^{\text {th }}$ centuries, and were accompanied by fast population growth (Czech Lands 1820 - a little more than 5 million, 1845 6.5 million, Fialová et al. 1998), which was absorbed predominantly by the new arising cities as the centres of industrial development. This century is by right called "the age of steam", because with the steam engine the industrial production multiplied and got cheaper, the transport got more efficient (faster and cheaper above all), and thus trade got more easier, and it brought new elements into the landscape and "enriched" it with the silhouette of smoking chimneys. Also it was a stimulus to change the former baroque landscape, when society made use of local sources (main source of energy was water, wind and firewood), into the modern landscape with rising number of technical elements and where society depended on fossil energy sources. 
The Agricultural Revolution was based on the change in management of land fund from fallow system of farming into four-field crop rotation, accompanied by the introduction of root crop and fodder plants. These changes together with the beginnings of mechanisation and using of fertilisers resulted in the intensification of agricultural production, the yields increased by half and there was more labour force necessary for the increasing industrial production.

Four-field crop rotation in Moravia was first used in 1808 at the farm in Mělčany, a neighbouring village of Dolní Kounice (Lneničková 1999).

The presented text is a historical-geographical study of a small Moravian town of Dolní Kounice, which was carried out by analysing the data from the Franciscan Cadastre of this town located $20 \mathrm{~km}$ southwest of Brno, in dissected landscape at the border of Bobrava Highlands and Dyjsko-svratecký úval Graben (see Fig. 1).

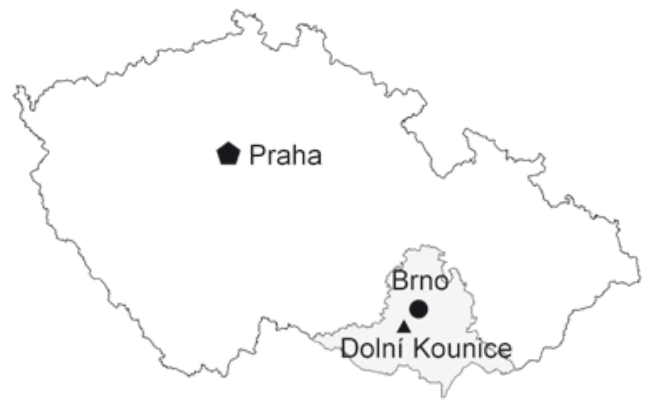

Fig. 1 Location of Dolní Kounice - area of interest

\section{Data and methods}

Let us view the landscape and its development as it is on the palimpsest (Cílek 2004, Gojda 2000), when each new epoch leaves its imprint on the landscape and at the same time erases one part of the existing landscape. Then the imaginary sheet of parchment describing the landscape of the $19^{\text {th }}$ century is still preserved very well without any later changes, and this is mainly due to the Stabile Cadastre.

The beginnings of the Franciscan Cadastre creation, a large piece of work at that time, were connected with the Patent of Emperor Franz I on land tax and land survey dated from December 23, 1817. This new cadastre was to substitute former cadastre registers and its main objective was to increase the efficiency of land tax collection. The following suggestions, which were among others included in the patent, are essential for landscape study and land use (Kuchař 1961, Novotný 1911, Mašek 1948, Bumba 2007):

- cadastre will include all property,both cultivated and not cultivated, disregarding manorial or servile land,

- properties will be located geometrically, portrayed, written down and described,

- properties will be differentiated according to their type and use.

The authors of the new cadastre were aware of its extent and ambitiousness, it was meant to create a permanent and an immaculate list of all properties subjected to tax, 
with stating their size, location and net yield. It was titled the Franciscan Cadastre because of its thoroughness and for the idea that it will serve its purpose forever. Gradually all parts of the Austrian Empire, corresponding to the later formed Cisleithania, i.e. Bohemia, Moravia, Austrian Silesia, Lower and Upper Austria, The Salzburger Land, Styria, Carinthia, Krajina, Primorska, Dalmatia and Grand Duchy of Cracow (Kuchař 1961), were processed using the common methodology.

In this study we are going to use merely the two of its parts - the written records and the map records. The written operate of the Franciscan Cadastre of Dolní Kounice originated between 1840 and 1842, and now is deposited in Moravian Provincial Archive in Brno. The introductory 14 paragraphs are devoted to the highly detailed description of the whole cadastre, its physical-geographical conditions, population number, number of houses and families, economic activity of population, agriculture specialization, land use, industry, small businesses categories and road system. The other parts are in detail devoted to property classification according to their quality, calculating their net yield and tax assessing, nevertheless these data is employed only marginally in this text. The written records of the Franciscan Cadastre define ten types of land use in Dolní Kounice. The arable land, pastures, vineyards, gardens, built-up area, forest, arable land with fruit trees, pastures with fruit trees, pastures with trees and shrubs and crop-fallow system are explicitely defined here.

The written records was created before the introduction of the metric system, and for this reason Joch (Jitro $=0.5755$ hectares) and Klafters (Fathoms, 1 fathom $=3.5966$ square metres) are used as measures of area. It has to be emphasized that all records were taken in German and in most cases written by hand in kurent script (the handwritten version of German, not used any more today), which makes the translation more difficult and use of such extensive documents is limited.

The map records consists of cadastral maps depicting all properties, both cultivated and others (unproductive) lands. For the use of this study the colourized Imperial Imprints of the Franciscan Cadastre were used, which record the actual condition of land use at the time of its mapping, that is in 1825, without any later modifications. In case of Dolní Kounice there is a file with eight map fields on six map sheets, administrator of which is the Czech Office for Surveying, Mapping and Cadastre in Prague. The internet presentation of its collections is available at http://archivnimapy.cuzk.cz/.

\section{Dolní Kounice in the light of the Franciscan, so-called "Stabile" Cadastre}

Data from the written records of the Franciscan Cadastre of Dolní Kounice can be categorized as follows: settlements and population, agriculture and land use, trade, industry and small businesses.

\subsection{Settlement and population data}

The introductory parts are devoted to the detailed topographic characterization of the whole cadastral area of Dolní Kounice, the description of boundary lines including the numbering of all neighbouring cadastral areas. The town location is defined with 
respect to Brno and main communications. The cadastre is described as follows: "Southwest of the provincial capital city Brno and on the right of the main passing road to Wien, an area with a settlement is spreading, substantial part of which lies in the large valley of Jihlava river stretching from southeast to northwest. The surface is uneven, deeply cut with riverbed of Jihlava river, the climate is mild, rather dry than wet." The entire cadastre area occupies 1556 jochs and 1259 klafters (895.9 hectares). Unlike in the works using the Database of LUCC UK Prague, it was not necessary to deal with the land comparability problems since the present-day cadastre of Dolní Kounice has changed very slightly (it has increased by 1.3 hectares to 897.2 hectares since then).

The German name of the municipality was Kanitz, its Czech or, as it is stated in the records, "Moravian" equivalent is Kanice. The language spoken is Moravian, but a lot of people spoke German too. In 1840 the population of Kounice was 2792 (1295 men and 1497 women). 620 families lived in 396 tenanted houses, which is 1.55 family with 7 members in one house on average, 126 townspeople owned houses, there were 223 house owners (people living in a family house), the Jews owned 35 houses. With the later revision of the written records population number in 1843 was added, which slightly raised population to 2805 (1300 men and 1505 women). The population density was 313 people per square kilometre, whereas the average of the Czech Lands was in 1850 only 84 people per square kilometre (Kárníková 1965).

In the alluvial plain of the Jihlava river there is a compact built-up area, the only exception being a small settlement Karlov, two kilometres to the north of the centre. The compact built-up area is surrounded by gardens representing a zone of transition into open (mainly) agricultural countryside dominated by arable land. The town is divided into two parts by the Jihlava river and joined with a wooden bridge where the toll was being collected. Its right bank part is larger and of greater importance, with the square and the town hall and other significant buildings that can be precisely located owing to the Franciscan Cadastre. They are religious buildings and authority buildings in particular. The marketplace was the central part of the city, surrounded by timber-frame houses, parish church (damaged by flood in 1862 and pulled down subsequently), St. John's chapel at the highest point of the central part of the town and the nearby manor yard with the brewery and the mill. On the hill above the town a "manor chateau" is towering - "the cradle of the Kaunitz family, now owned by the prince of Dietrichstein-Proskau-Leslie and the seat of manor authorities". The last significant part is the Jewish district in the western side of the marketplace. (In 1850 the Jewish community had 649 members, which was approximately a quarter of the total population number.) The built-up area on the left bank of the river is mentioned in the Stabile Cadastre only marginally, the dissimilar social status of its population being mentioned: "the houses are inhabited with poor people". The built-up area is of bricks or stone (inflammable), the minimum of buildings are wooden, involving farm buildings in brickworks premises and some house background near the manor yard. Other significant buildings are spatially localized on the enclosed scheme (Fig. 2). 


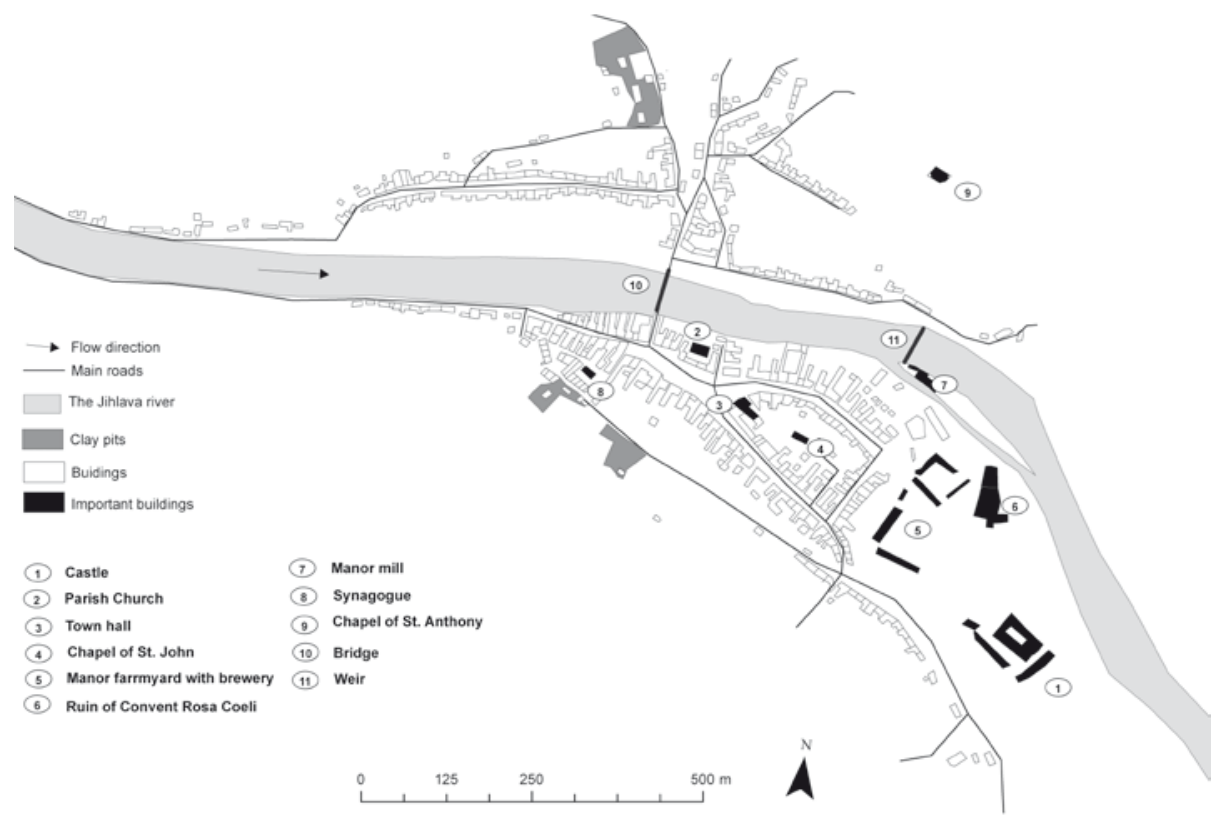

Fig. 2 Built-up area of Dolní Kounice according to Franciscan "Stabile" Cadastre Source: Cadastral Schätzungs operat der steuergemeinde Kanitz. MZA Brno, D8, sign. 451

The river was partly regulated by the weir, of which took advantage the mill, the Franciscan Cadastre even mentions an expensive earth embankment to protect fields between Dolní Kounice and Pravlov; the river was not regulated in any further way and the riverbed had got clogged and alluvial fan of gravel deposits on the banks created. The Franciscan Cadastre describes the regularly recurrent spring floods "after a spring thaw and rain the riverbed is not capable of retaining such amount of water and subsequently the flood is so strong that the major part of the town on both banks of the river is not only flooded by water but also covered with sand".

\subsection{Agriculture and land use data}

Agriculture and land use data is described in high detail since it was the most important item for tax assessing. The share of land used in agriculture was $87.7 \%$ in Dolní Kounice, the second most significant category with $10.1 \%$ was unproductive land (water bodies, rocks, roads) that was not liable to taxes. Built-up areas amounted solely to $1.5 \%$ and forests just $0.7 \%$ of the cadastral area (see Fig 3 ).

The most frequent type of land use included is arable land, which is divided by the written records into four categories according to its quality (category I 44.4 hectares, category II 100.6 hectares, category III 111.5 hectares and category IV 101.1 hectares).

The three year crop rotation system of farming still dominates, and it was subjected to criticism in the comment on agricultural production "when cultivating soil to grow stalky plants and legumes the land owners are not developed, nobody excels here and thus cannot set a good example for the rest". 


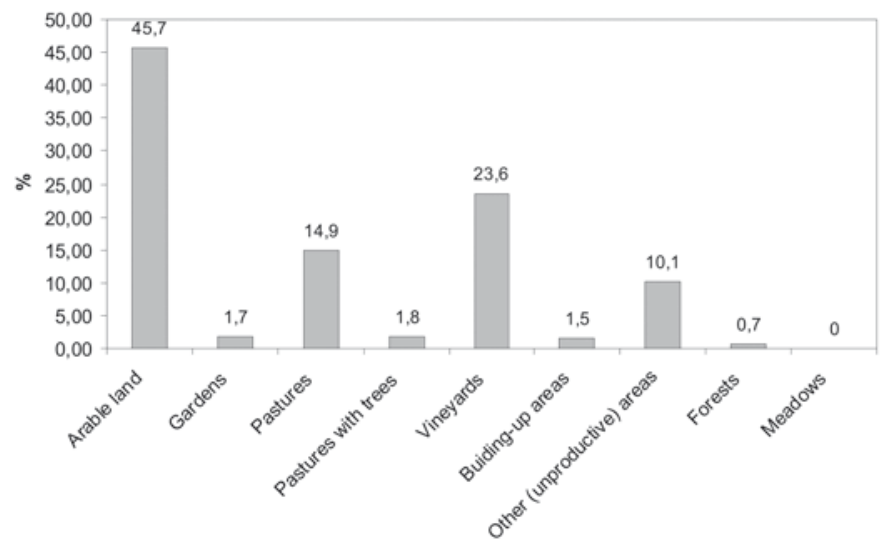

Fig. 3 Areas of land use classes in cadastre of Dolní Kounice according to written operate of Franciscan "Stabile" Cadastre (year 1841)

Source: Cadastral Schätzungs operat der steuergemeinde Kanitz. MZA Brno, D8, sign. 451

As an example of arable land management we can take the system of farming the field of the category I. There were 44.4 hectares on 9 plots delimited (the size of these land blocks was more than twenty times bigger than the average size of the field parcel which was 0.24 hectares). Soils of the best quality were located in a slightly undulating southern part of the cadastre. In the first year three quarters of the fields were cultivated with winter wheat and one quarter with rye, in the second year three quarters with barley and one quarter with oats, in the third year it lied fallow and was fertilized a lot. Supposed crop yield in the first year was 22 measures of wheat $(1$ measure $=61.5$ litres) and 24 measures of rye, in the second year 24 measures of barley and 28 measures of oats.

The main crops are winter wheat, winter rye, barley, oats, lentil, beans and potatoes, in smaller amount peas and corn. Fields with fruit trees ( 24.5 hectares) can also be placed within this category, fruit trees taking one third of the area and the rest being cultivated as regular arable land. In between pasture and arable land there is a category called the crop-fallow system (in German Trisch Aecker), these areas were situated particularly at steep slopes with not much fertile soil full of skeleton, especially in the northern part of the cadastre; in the Franciscan Cadastre there are 27.2 hectares of such areas. The four-year crop rotation was based on production of potatoes and beans in one year and then leaving it fallow as pastures for sheep.

Farm surpluses were offered at the local marketplace or delivered to the market in Brno. $52.1 \%$ of the agricultural land made fields. If we take into account the fallow system then the actual arable soil declines at least by one third to $35 \%$, even more with counting in the crop-fallow system.

The second most important component of agricultural land were vineyards. There were 211.5 hectares of them, which was $26.9 \%$ of agricultural land. They were called Wechselweingarten in German, which may be translated as rotating, or transitional vineyards. The term represents the substance of the farming on these areas that is, rotating grapevine and arable soil. The cycle of the rotation lasted for 36 years. First it was used for grapevine and then it was switched to arable soil. The vineyard was set 
up with seven to eight thousand grape plants per one Joch $(12,165-13,903$ plants per hectare). Both red and white wine were grown, the crop being described as good, but "from time to time the yield is in doubt due to its unsuitable location". The manor yard alone had some major surpluses; most of the wine was nonetheless used up on the spot or in its nearby vicinity.

The average size of the vineyard plot was purely 0.0185 hectares. The vineyards were divided in a similar way like arable soil, into four categories according to their quality (category I of 36.3 hectares, category II of 102.1 hectares, category III of 66.7 hectares, category IV of 6.4 hectares), the decisive factor being the soil quality and the plot aspect. The grapevine is grown on the left bank part of the cadastre in the zone between 230-320 metres above sea level.

Pastures were highly important for grazing of livestock, at that time without any housing of cattle. Pastures were situated on lands of bad exploitation, especially on steep slopes, in valleys of small streams and gorges, along the roads and between the field blocks. According to their complementary utilization they were divided within the Franciscan Cadastre into three categories: pastures utilized solely for grazing (133.45 hectares), pastures with fruit trees (14.1 hectares, especially castle hill and pastures around the Karlov settlement ) and pastures with shrubs and trees (1.6 hectares). If we include three quarters of crop-fallow land that was also utilized for grazing, then the grazing land totals 170 hectares. The communal pastures were the largest (in the map marked as GW), localized along the Jihlava river and in the northern part of the cadastre by the Karlov settlement. According to the Franciscan Cadastre pastures are defined as not much fertile: "pastures have very low-quality grass and thus are no good for livestock".

The total amount of livestock specified in the Franciscan Cadastre was 30 horses, 2 bulls, 116 cows, 35 calves, 900 sheep of good breed and 120 pigs. Horses, cattle and pigs were loosely housed, which was commented on by the author of the records: "the biggest disadvantage is the loose-housing of cattle, which is a farming system that only hinders the production of meat and manure". The biggest farmstead in Dolní Kounice was the manor yard, where there were 6 horses, 20 cows, calves and 30 pigs.

The last part of the agricultural land is gardens, which were a direct follow-up to the built-up area, and were part of each house background and were utilized for growing fruit and vegetables. Gardens were divided into two groups according to their quality. The first category included larger flatlands near the river, the second included steeper lands of higher altitude. The average size of a garden was 0.056 hectares. The most frequentlygrown fruit trees, both within and outside the gardens, were cherry trees, sour cherry trees, pear trees and prune trees, exceptionally walnut trees, peach trees and apricot trees. Cultivated varieties did not flourish there according to the Franciscan Cadastre. Among vegetables cucumbers, lettuce and cabbage are mentioned in the Franciscan Cadastre.

Built-up areas totalled 13.1 hectares, most of the houses were built of solid materials, with tiled roof and in a rather good condition, buildings located outside the centre, particularly on the left bank of the river, had walls of clay and thatched roof, nevertheless their condition being also assessed as fairly good. "There are few building plots, we can acquire them solely from gardens." The above mentioned complies with the later construction development, when the built-up area had been thickening rather than spreading spatially. Besides the above mentioned buildings 
and institutions there were vicarage, school, synagogue, town hall, poorhouse, hospital and an isolated inn on the Charles' hill (Karlův kopec). There were only few forests, primarily at the northern boundary of the cadastre, totalling 6.8 hectares of coniferous forest, and also mixed forest on one plot. Spatial distribution of this basic land use unit presents Fig. 4.

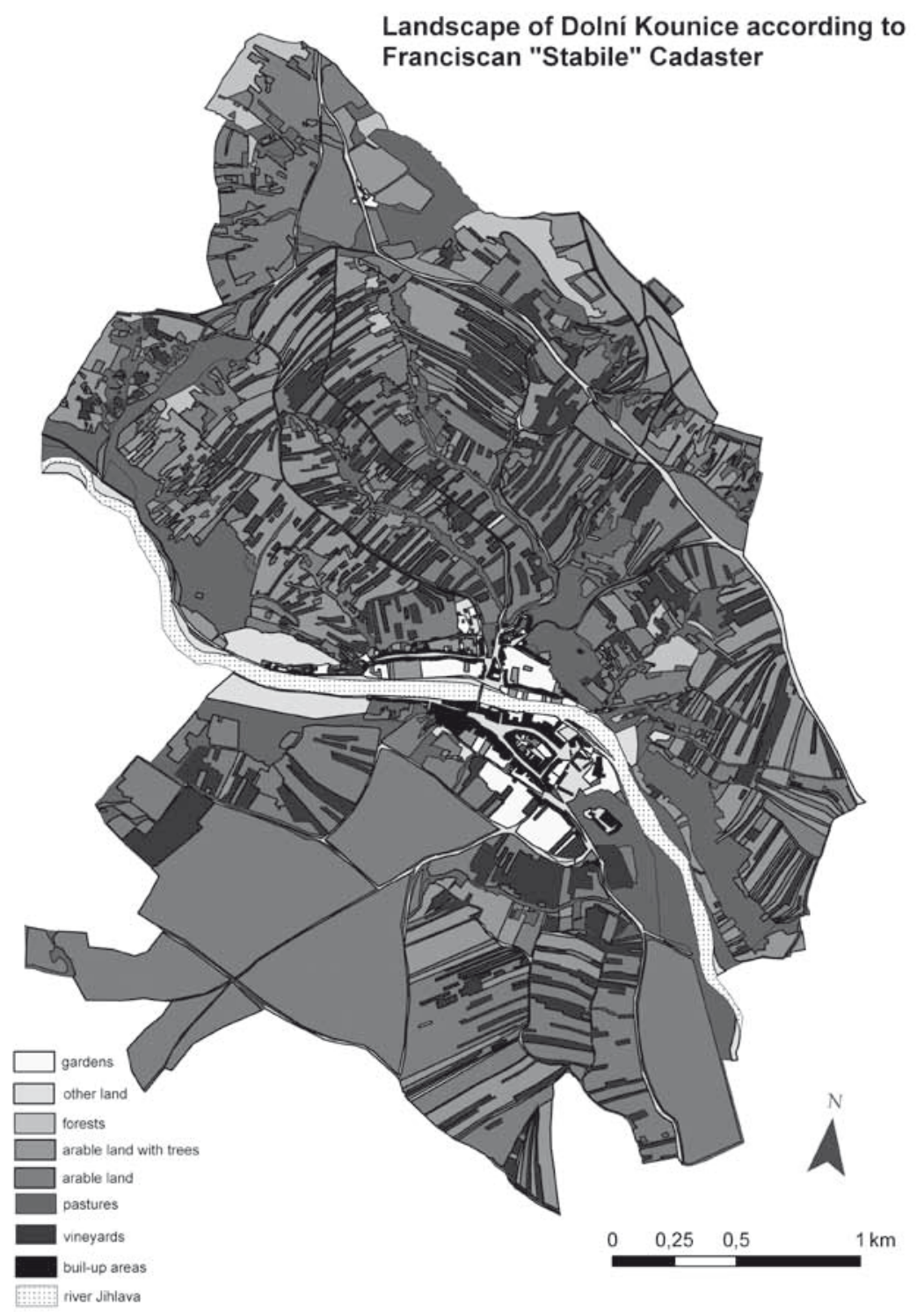

Fig. 4 Landscape of Dolní Kounice according to Franciscan "Stabile" Cadastre

Source: Imperial prints of Franciscan "Stabile" Cadastre of Dolní Kounice (Central Archives of Surveying, Mapping and Cadastre, Prague) 
Industrial production in Kounice was in its early days, yet there was a steam engine ( 8 horsepower) in the textile factory. The factory of Arnošt Baltazar was the largest employer (30 men and 50 women workers). The market of its products was in nearby Brno, it also dealt with Wien, Hungary and Galicia. Fuel for the steam engine came from black coal mine in the nearby Rosice, the consumption totalled 1800 quintals ( 1 quintal $=56 \mathrm{~kg}$ ) and consumption of wood was 150 fathoms $(1$ fathom $=1.52$ cubic metres) from close neighbourhood. Other larger enterprises were manor brewery and mill. According to the Stabile Cadastre there were seven distilleries whose annual output was 400 bucketfuls of spirit ( 1 bucketful $=61.117$ litres/or 56.6) made from potatoes and rye for local people and close neighbourhood. Three brickworks with annual output of 300,000 bricks and 60,000 roof tiles made use of heavy loess blankets, and by the Franciscan Cadastre "is hardly sufficient for the requirements of the town and neighbouring villages, where the construction of solid buildings culminates". The main source of energy in the town is black coal, which is caused by little wood supply and proximity of black coal mines, the annual consumption being approximately 2160 quintals according to the Franciscan Cadastre. There are 24 small businesses that satisfy population consumption at that time, and thus Dolní Kounice was the centre of commerce and trade, also for its close neighbourhood. There was one doctor, one manor and one Jewish dentist in the town.

Agriculture was the means of subsistence for most families, though only a few were devoted solely to it, having been engaged in various small busenesses and trade, or worked on a Wien-Brno railroad. Jewish people were engaged in commerce and enterprise despite the restrictions.

\section{Land use analysis}

In the table 1 comparison of data from the Franciscan Cadastre from 1841 with the data from 1845 (data from Central Archives of Surveying and Land Register, on which Prague database of LUCC works too) is shown in Table 1.

Table 1 Land use categories in Dolní Kounice in years 1845 and 1841

\begin{tabular}{|l|l|c|c|}
\hline Basic land use categories & Specified categories & year 1845 & Stabil Cadastr (1841) \\
\hline \multirow{4}{*}{ Arable land } & Arable land & 348.8 & 357.6 \\
\cline { 2 - 4 } & Arable land with fruit trees & 164.2 & 24.5 \\
\cline { 2 - 4 } & Land with crop-fallow system & not mentioned & 27.2 \\
\cline { 2 - 4 } & SUM & $\mathbf{5 1 3 . 0}$ & $\mathbf{4 0 9 . 3}$ \\
\hline \multirow{3}{*}{ Gardens } & Vegetable gardens & 3.8 & \multirow{2}{*}{15.6} \\
\cline { 2 - 4 } & Fruit gardens & 11.3 & \\
\cline { 2 - 4 } & SUM & $\mathbf{1 5 . 1}$ & $\mathbf{1 5 . 6}$ \\
\hline
\end{tabular}




\begin{tabular}{|c|c|c|c|c|}
\hline \multirow{2}{*}{ Vineyards } & & & 121.8 & 211.5 \\
\hline & \multicolumn{2}{|l|}{ SUM } & 121.8 & 211.5 \\
\hline \multirow{4}{*}{ Pastures } & \multicolumn{2}{|c|}{ Pastures } & 110.4 & 133.3 \\
\hline & \multicolumn{2}{|c|}{ Pastures with fruit trees } & not mentioned & 14.1 \\
\hline & \multicolumn{2}{|c|}{ Pastures with trees } & not mentioned & 1.6 \\
\hline & \multicolumn{2}{|l|}{ SUM } & 110.4 & 149.0 \\
\hline Agricultural land & \multicolumn{2}{|l|}{ SUM } & 760.2 & 785.4 \\
\hline \multirow{5}{*}{ Forested areas } & \multirow{3}{*}{ forests } & hardwoods & not mentioned & \multirow{4}{*}{6.8} \\
\hline & & coniferous & 14.0 & \\
\hline & & mixed & 3.0 & \\
\hline & \multicolumn{2}{|l|}{ Bushes } & 17.2 & \\
\hline & \multicolumn{2}{|l|}{ SUM } & 34.2 & 6.8 \\
\hline \multirow{2}{*}{ Built-up areas } & & & 19.9 & 13.1 \\
\hline & \multicolumn{2}{|l|}{ SUM } & 19.9 & 13.1 \\
\hline \multirow{3}{*}{ Unproductive land } & \multicolumn{2}{|l|}{ Rocks } & 36.2 & \multirow{2}{*}{90.6} \\
\hline & \multicolumn{2}{|c|}{ Gravel, stone and clay pits } & 1.2 & \\
\hline & \multicolumn{2}{|l|}{ SUM } & 37.4 & 90.6 \\
\hline \multirow{3}{*}{ Other areas } & \multicolumn{2}{|c|}{ Rivers and streems } & 25.2 & \multirow{2}{*}{ not mentioned } \\
\hline & \multicolumn{2}{|l|}{ Roads } & 18.9 & \\
\hline & \multicolumn{2}{|l|}{ SUM } & 44.1 & not mentioned \\
\hline Other areas & & & 101.3 & 103.7 \\
\hline SUM & & & 895.9 & 895.9 \\
\hline
\end{tabular}

Source: 1841 - Cadastral Schätzungs operat der steuergemeinde Kanitz. MZA Brno, D8, sign. 451, 1845 Ústřední archiv zeměměřictví a katastru (Central Archives of Surveying and Land Register) - own calculations

At first sight we can notice a disagreement in the categories used and in total area amount. The total cadastre area did not change, it totalled 895.9 hectares both according to the Franciscan Cadastre and the data from 1845. It is debatable then whether such changes were natural or due to the different methodology used with cadastre survey.

According to these data the agricultural land decreased by 25.2 hectares (3.3\%), forest area increased by 27.4 hectares (relatively by enormous $403 \%$ ) and other areas decreased by 2.5 hectares $(2.4 \%)$. Changes within these comprehensive categories are not enormous and could be explained by forestation of the worst agricultural land and other areas (after all, the trend of forest expansion had been described since that 
period). When we take a closer look at the various categories it is rather impossible to make simple judgements. There are big differences in arable land areas that increased by as many as $20 \%$, on the contrary areas of vineyards and pastures substantially decreased. Vineyards by as many as 89.3 hectares (by nearly $43 \%$ ), pastures by 38.6 hectares $(26 \%)$, the only comparable being gardens that decreased simply by 0.5 hectares $(3 \%)$. Such changes might be explained by switching part of the rotating vineyards that were in their field use (see above) into the category of arable land, switching pastures into forests and in part, into arable land. We do not have any detailed information about arable land structure, and thus the question of increase of fields with fruit trees category remains unsolved and requires a more detailed analysis.

Forest area, according to this data, is the most expanding category. The Franciscan Cadastre defined few forests that were dominated by coniferous trees, in contrast to this, in 1845 the cadastre records stated almost triple the coniferous and mixed forests! A category that is not part of the Franciscan Cadastre any more and at the same time makes approximately one half of the forest area (17.2 hectares) are shrubs. Such vegetation was included within pastures with firewood and was probably part of further pasture categories and unproductive land.

The category of built-up areas experienced significant growth, almost by $49 \%$ in this period. Such increase is in contrast with small decrease of gardens that were all around the town at that time and were primarily used as building plots. Other factors such as small population increase also deny such building expansion; the reason being rather category changes (in this case including adjacent courtyards, handling areas and the like, within this category).

Such short enumeration of the most significant differences between land use categories in the Franciscan Cadastre and the records from 1845 implies that these two data files are not to be compared with each other on the basis of elementary land use categories (arable land, vineyards, gardens, pastures...), but merely by using higher land use categories (agricultural land, forested areas, and other areas), doing so with the utmost caution. There are differences in the methodology of categorizing individual areas, the employed categories being distinct too, some specifying, some generalizing. Therefore it is difficult to distinguish the natural development from the changes that were influenced by the methodology, and the resulting changes are their combination in which, in my opinon, the methodological aspect of changes prevails.

\section{Conclusion}

The Franciscan Cadastre is a compact and as objective as possible piece of work, dealing with both quantitative and qualitative condition of land fund and economy in the Czech Lands, Moravia and Silesia, and also Austria and Dalmatia. It is unique in its details and extent, both factual and spatial, and its uniform rules according to which it originated and which make it easier to compare its outputs, even in the international context. The detailed map operate of Franciscan Cadastre is highly valued since $70 \%$ of contemporary cadastral maps still make use of it (Pešl 2001), which speaks for itself. The written records is rich in detailed historical-geographic data concerning the whole 
cadastral area, which could be arranged into three categories: data concerning settlement and cadastre, information about agriculture and land use, data concerning industry, trade and small businesses. The landscape of Dolní Kounice as depicted in the Franciscan Cadastre is a landscape in transition; the Agricultural Revolution still was not manifested here in its full shape, not introducing crop-fallow rotation and other methods of intesification. As far as industry is concerned it is just the contrary industrial production is in its boom time; the most significant enterprises being textile factory and brickworks, the town is the economic and commercial centre for its neighbourhood. The landscape of the cadastre is characteristic by high spatial variation of land use classes, forming a very fine mosaic of fields, vineyards and pastures, especially on the left bank of the river. It is obvious from the map records that there is an effort to utilize every possible land - pastures are in the river valleys and on rather steep slopes, bare rocks being the only area unexploited. The town is shaped by the relief and the river that splits it up into the centre (on its right bank) and periphery on the left bank. The poor transport connection of Dolní Kounice and its location off the trade routes and railroads resulted in the town stagnation in later years. It is rather disputable whether the data stated in the Franciscan Cadastre of 1841 and in cadastral records from 1845 is comparable, since partly diverse land use categories were applied (some of them specifying, some generalizing) together with diverse assessment methods for individual areas. Changes within specifying categories of these land use types beg more questions than huge decrease in number of vineyards and pastures and increase in arable soil, forests and built-up areas. It follows that such two data files cannot be contrasted on the basis of basic land use categories, but only using comprehensive categories (agricultural land, forests and others). The question is whether such findings hold true solely for the studied cadastre, or whether we can draw a general conclusion concerning the whole Franciscan Cadastre. Disregarding such fact the Franciscan Cadastre is an indispensable source of detailed written and map information concerning population and landscape of the first half of the $19^{\text {th }}$ century. It is unique both for its comprehensiveness and artistic elaboration and for its historic value.

\section{References}

BIČÍK, I., JELEČEK, L. (2003): Long Term Research of LUCC in Czechia 1845-2000. In: Jeleček, L. et al. (eds.): Dealing with Diversity. $2^{\text {nd }}$ International Conference of the European Society for Environmental History, Prague, 2003. Proceedings. KSGRR PřF UK, Prague, pp. 224-231.

BIČÍK, I. (2004): Dlouhodobé změny využití krajiny České republiky. Životné prostedie, 38 (2), pp. 81-85.

BIČÍK, I., JELEČEK, L., ŠTĚPÁNEK, V. (2001): Land use chnages and their social driving forces in Czechia in the $19^{\text {th }}$ and $20^{\text {th }}$ centuries. Land use policy, 18 , No. 1, pp. 65-73.

BOLTIŽIAR, M. et al. (2008): Potential of antique maps and aerial photographs for landscape changes assessment - an example of the High Tatra Mts. Ekológia 27, (1) ILE SAS, Bratislava, pp. 65-81.

BRU゚NA, V., KŘOVÁKOVÁ, K. (2006): Interpretation of Stabile Cadastre Maps for Landscape Ecology Purposes. International Conference on Cartography \& GIS. Borovets, Bulgaria.

BUMBA, J. (2007): České katastry od 11. do 21. století. Grada Publishing, a.s., Praha, 190 p.

CÍLEK, V. et al. (2004): Vstoupit do krajiny. Dokořán, Praha, 112 p.

DRÁPAL, M. (1975): Význam oceňovacích operátů pro historicko-geografická bádání na Moravě. Folia PřF UJEP XIV - Geographica 9 (13), pp. 73-81. 
FERANEC, J., OŤAHEL, J. (2009): Land cover/land use change research and mapping in Slovakia. Geographia Slovaca 26, pp. 169-190.

FIALOVÁ, L. et al. (1998): Dějiny obyvatelstva českých zemí. Mladá Fronta, Praha, 398 p.

GOJDA, M. (2000): Archeologie krajiny: vývoj archetypů kulturní krajiny. Academia, Praha, 238 p.

JELEČEK, L. (1995): Využití půdního fondu České republiky. Geografie - Sborník ČGS, 100 (4), pp. 39-45.

KABRDA, J. (2004): Influence of natural conditions on land use in the Vysočina region and its changes since the mid-19 $9^{\text {th }}$ century. AUC - Geographica 39 (2), pp. 15-38.

KAIN, R. J. P., BAIGENT, E. (1992): The Cadastral Map in the Service of State. A History of Property Mapping. University of Chicago Press, Chicago, 423 p.

KAŠPAR, J. (1997): Čelákovice roku 1842. Historicko-topografický obraz města podaný na základě údajů stabilního katastru. Historická geografie, 29, pp. 103-151.

KARNIKOVA, L. (1965): Vývoj obyvatelstva v českých zemích 1754-1914. Nakladatelství ČSAV, Praha, $401 \mathrm{p}$.

KUCHA ̌̌, K. (1961): Vývoj mapového zobrazení Československé socialistické republiky, III. díl, Mapování a měření Českých zemí od pol. 18. stol. do počátku 20. stol. - Ústřední správa geodézie a kartografie, Praha, $80 \mathrm{p}$.

KUCHA ̌, K. (1967): Mapové prameny ke geografii Československa. AUC - Geographica 2 (1), pp. 57-97.

LIPSKÝ, Z. (2000): Sledování změn v kulturní krajině. Lesnická fakulta ČZÚ, Praha, 72 p.

LNĚNIČKOVÁ, J. (1999): České země v době předbřeznové 1792-1848. Libri, Praha, 463 p.

LUCC UK Prague database - database of the project of the Grant Agency of the Czech Republic GAČR 205/05/0475: Driving forces of land use differentiation in Czechia and in neighbouring countries; prospects of development after joining the EU.

MACKOVČÍN, P., DEMEK, J., HAVLÍČEK, M. (2007): Význam historických map pro studium vývoje krajiny ČR za posledních 250 let. Geografická revue 2 (2), pp. 159-171. Banská Bystrica.

NOVOTNÝ, F. (1911): Nauka o rakouském katastru a o knihách pozemkových. Praha.

MAŠEK, F. (1948): Pozemkový katastr. Soupis, popis a geometrické zobrazení pozemků ČSR. Ministerstvo financí ČSR, Praha, 223 p.

OLAH, B. (2003): Vývoj využitia krajiny podpol'ania. Technická univerzita vo Zvolene, Zvolen, 110 p.

PEŠL, I. (2001): Ještě k výměrám parcel (nebo pozemků?). Zeměměřič $8(8+9)$.

SÁDLO, J., KARLÍK, P.(2002): Krajinně-ekologické interpretace starých map prostřednictvím geobotaniky: příklad Josefského mapování. In: Němec, J. (ed.): Krajina 2002 - od poznání k integraci. Ústí nad Labem, MŽP ČR, pp. 58-63.

SEMOTANOVÁ, E. (2001): Mapy Čech, Moravy a Slezska v zrcadle staletí. Libri, Praha, 263 p.

ŠTĚPÁNEK, V. (1996): Data o struktuře ploch: jejich spolehlivost a vypovídací schopnost. Geografie Sborník ČGS 101, (1), pp. 13-21.

Císařský povinný otisk Stabilního katastru Dolních Kounic $1: 28$ 000, Ústř̌ední archiv zeměměřictví a katastru. Praha.

Cadastral Schätzungs operat der steuergemeinde Kanitz. MZA Brno, D8, sign. 451.

Résumé

Krajina Dolních Kounic z pohledu autorů Františkánského („Stabilního“) katastru

Stabilní katastr, podle panovníka který inicioval jeho vznik též Františkánský katastr, je ucelené, na svoji dobu maximálně objektivní a přesné dílo o kvantitativním i kvalitativním stavu půdního fondu a ekonomiky v Čechách, na Moravě a ve Slezsku, ale i Rakousku a Dalmácii. Unikátní je svojí podrobností, rozsahem věcným i územním a jednotnými pravidly, podle nichž vznikal a které usnadňují porovnatelnost jeho výstupů i v mezinárodním kontextu. Velice cenný je precizně zpracovaný mapový operát Stabilního katastru, ze kterého doposud ještě vychází 70 \% současných katastrálních map (Pešl 2001), což hovoří za vše. Písemný operát je bohatý na detailní historickogeografická data o celém katastrálním území, jež by se dala seřadit do tř́ kategorií: údaje o sídle a katastru, informace o zemědělské výrobě a využití půdy, údaje o průmyslové výrobě, obchodu a živnostech. 
Krajina Dolních Kounic, jak ji zachytil stabilní katastr, je krajinou na přelomu barokní a novověké éry. Stále se zde plně neprojevila zemědělská revoluce v podobě systému střídavého hospodářství a dalších intenzifikačních opatření, ale z pohledu průmyslu je tomu naopak, průmyslová výroba se zde již rozvijí, nejvýznamnějším podnikem je textilní továrna a cihelny, město je hospodářským a obchodním centrem pro blízký region. Krajinné pokrývce dominuje mozaika polí, vinic a pastvin, která je zejména na levobřežní části katastru velmi drobná a pestrá. Z mapového operátu je patrná snaha o využití každého možného pozemku - pastviny jsou $\mathrm{v}$ údolích vodotečí i na velmi strmých svazích, neobhospodařované zůstávají prakticky jen holé skály. Město je determinováno reliéfem a řekou, která ho dělí i významově na jádro (centrum města na pravém břehu) a periferii na levém břehu. Špatné dopravní napojení a poloha Dolních Kounic mimo hlavní obchodní cesty a železnici vedla v pozdější době k jeho stagnaci.

Srovnatelnost dat o využití půdy vedených v rámci Stabilního katastru, tedy z roku 1841, a z katastrálních výkazů z roku 1845 není v prípadě Dolních Kounic jednoznačná, protože byly použity z části jiné kategorie využití půdy (některé upřesňující, jiné naopak generalizující) a zréejmě i odlišné postupy při hodnocení jednotlivých ploch. $Z$ porovnání vyplývá, že tyto dva datové soubory nelze mezi sebou porovnávat na základě základních kategorií land use, ale jen pomocí souhrnných kategorií (zemědělský půdní fond, Lesní plochy a jiné), podobně jak to popisuje metodika použitá tvůrci databáze LUCC UK. Vzhledem k přesně danému postupu při torbě Stabilního katastru i při pozdější tvorbě katastrálních výkazů lze očekávat podobné nesrovnalosti také v ostatních katastrálních územích.

Petr Dvoŕák
Institute of Geonics, AS CR
Departement of Environmental Geography
Studentská 1768
708 00 Ostrava
Czech Republic
tel.: +420596979327
e-mail:dvorak@geonika.cz

